\title{
Phenethyl isothiocyanate induces cell cycle arrest and reduction of $\alpha$ - and $\beta$ - tubulin isotypes in human prostate cancer cells
}

\author{
Ping Yin, Tomoya Kawamura, Meilan He, Donkena Krishna Vanaja, and Charles Y.F. Young* \\ Department of Urology, Mayo Clinic College of Medicine, Mayo Clinic/Foundation, 200 First St. SW, \\ Rochester, MN 55905, USA.
}

\begin{abstract}
This study was to investigate the effect of phenethyl isothiocyanate (PEITC), a constituent of many edible cruciferous vegetables, on the expression of $\alpha$ - and $\beta$ - tubulins, which are the main components of microtubules in prostate cancer cells. Flow cytometry, light microscopy and western blot were used to study the cell cycle distribution, morphology changes and the expression of $\alpha$ - and $\beta$ - tubulins in prostate cancer cells treated with PEITC. The results showed that PEITC induced G2- M cell phase arrest and inhibited the expression of $\alpha$ - and $\beta$ - tubulin proteins in a number of human prostatic carcinoma cell lines. Further, it is showed that this inhibitory effect could be reversed by anti-oxidant $\mathrm{N}$-acetyl cysteine and proteasome inhibitor MG132. Finally, it is concluded that PEITC inhibited the expression of $\alpha$ - and $\beta$ - tubulins in prostate cancer cells, which is at least related to the oxygen reaction species and protein degradation.
\end{abstract}

\section{Keywords}

Phenethyl isothiocyanate; cell cycle; tubulin; prostate cancer

\section{Introduction}

Prostate cancer ( $\mathrm{PCa}$ ) is the most commonly diagnosed and the second leading cause of cancer death in males of the United States. Although advances in early detection and treatment have been contributed to decrease in mortality, it was still estimated that there would be around 27,000 of PCa deaths in the year 2007. (Jemal et al., 2007) Also there are a significant number of men requiring systemic therapy and ongoing surveillance for advanced PCa. (Walczak et al., 2007) Therefore, exploration of novel approaches and agents for prevention and treatment of PCa continues.

Microtubules are composed of a backbone of $\alpha$ - and $\beta$-tubulin heterodimers and microtubuleassociated proteins. (Howard et al., 2003) They are major cellular components that play crucial roles in a number of functions, including the maintenance of shape, adhesion, signaling, replication and cell division. It has been suggested that the microtubules can be affected by numerous endogenous regulators and exogenous factors, and are considered as a susceptible

\footnotetext{
*Corresponding author: Dr. Charles Y.F. Young, Department of Urology and Biochemistry/Molecular Biology, Mayo Clinic/Foundation, Guggenheim Building 5-02, 200 First Street SW, Rochester, MN 55905, E-mail: youngc@ mayo.edu, Tel.: (507) 284-8336, Fax: (507) 284-3757.

Publisher's Disclaimer: This is a PDF file of an unedited manuscript that has been accepted for publication. As a service to our customers we are providing this early version of the manuscript. The manuscript will undergo copyediting, typesetting, and review of the resulting proof before it is published in its final citable form. Please note that during the production process errors may be discovered which could affect the content, and all legal disclaimers that apply to the journal pertain.
} 
target by numerous therapeutic drugs. (Wilson et al., 1995) Several cancer chemotherapeutic drugs show their anticancer effects through the disturbance of microtubule dynamics, leading to dysregulation of mitotic spindles and the causative mitotic arrest in cancer cells. For example, paclitaxel and docetaxel bind to the microtubule lattice, stabilize microtubule bundles and impair cell mitosis in numerous types of cancer cells. (Manfredi et al., 1982; Rowinsky et al., 1997) In contrast, Vinca alkaloids bind to and inhibit microtubule polymerization, resulting in a blockade in mitosis and cell death. (Hadfield et al., 2003)

Isothiocyanates (ITCs) are found in cruciferous vegetables such as broccoli, watercress, brussels sprouts, cabbage, Japanese radish and cauliflower. Phenethyl-ITC (PEITC) is one of the most extensively studied ITCs, and recent epidemiological and experimental studies show that PEITC and other ITCs may possess promising cancer chemopreventive activities. (Higdon et al., 2007; Khor et al., 2006) In regard to PCa, PEITC has been found to reduce tumor cell growth by affecting signaling pathways, arresting cell cycle and causing apoptotic cell death in vivo (Xiao., et al, 2005, 2006) or in vitro. (Xiao et al., 2004; Butler et al., 2000) However, the exact mechanisms of its chemopreventive effects are not fully understood.

In this study, we aimed to investigate the effects of PEITC on tubulin expressions and cell proliferation in PCa cell lines by western blot and flow cytometry analysis. In addition, we assessed morphological changes with PEITC treatment using light microscopy, and then investigated the possible mechanisms of PEITC on tubulin expression. Our study suggests that anti-cancer effects of PEITC may potentially link to its repression of protein expression of $\alpha$ and $\beta$ - tubulin isoforms.

\section{Materials and methods}

\subsection{Reagents}

PEITC, PITC, and antioxidant N-acetyl-L-cysteine (NAC) were purchased from LKT laboratories (St. Paul. MN). Proteasome inhibitor carbobenzosy-L-leucyle-L-leucyl-L-leucinal (MG132) was purchased from EMD Biosciences (San Diego, CA). PEITC, PITC, and MG132 were dissolved in dimethyl sulfoxide (DMSO), which was also used as a control vehicle. NAC was dissolved in normal saline.

\subsection{Cell culture and treatments}

The human PCa cell lines (DU145, PC-3, LNCaP, and C4-2B) were routinely maintained in RPMI 1640 medium with 5\% fetal bovine serum (FBS) and 1\% penicillin/streptomycin under a humidified atmosphere of $5 \% \mathrm{CO}_{2}$ at $37^{\circ} \mathrm{C}$. Note, $\mathrm{C} 4-2 \mathrm{~B}$ is an androgen independent subline of androgen sensitive LNCaP cell line. Cells $\left(2.5-3 \times 10^{4} /\right.$ well $)$ were grown in 24-well plates for $2-3$ days and then treated with PITC $(20$ or $30 \mu \mathrm{M})$ or PEITC $(5,10$, or $20 \mu \mathrm{M})$ for 2,8 , or $24 \mathrm{~h}$. For antioxidant effect experiment, cells were treated with PEITC $(20 \mu \mathrm{M})$ in the presence or absence of NAC $(5 \mathrm{mM})$. For proteasome inhibitor effect experiment, cells were treated with PEITC $(20 \mu \mathrm{M})$ in the presence or absence of MG132 $(10$ or $20 \mu \mathrm{M})$.

\subsection{Analysis of cell cycle distribution}

The cell cycle distribution was analyzed as previously described with a slight modification (Butler et al., 2000). Briefly, cells were washed with PBS and fixed in 95\% ethanol for $1 \mathrm{~h}$ on ice. After washing with chilled PBS, pelleted cells were resuspended at $1 \times 10^{6} / \mathrm{ml}$ in PBS containing $5 \mu \mathrm{g} / \mathrm{ml}$ RNase A and incubated for $15 \mathrm{~min}$ at $37^{\circ} \mathrm{C}$. Samples were then incubated in PBS containing $5 \mu \mathrm{g} / \mathrm{ml}$ propidium iodide for $15 \mathrm{~min}$ at room temperature and analyzed by FACS assay (Becton Dickinson, Bedford, MA). The data were calculated as mean value \pm standard deviation for each groups, and analyzed by the Student's $t$ test. $P<0.05$ was considered to be statistically significant. 


\subsection{Western blot analysis}

Whole cell extracts at designated times were prepared by directly adding $1 \times$ NuPAGE $\AA$ LDS sample buffer (Invitrogen, Carlsbad, CA) to cells. Appropriate amount of each samples was separated on NuPAGE® 4-12\% Bis-Tris Gel (Invitrogen, Carlsbad, CA) and electrophoretically transferred to nitrocellulose membrane (Bio-Rad Laboratories, Hercules, $\mathrm{CA})$. The membranes were immediately stained by Ponceau $\mathrm{S}(0.1 \%$ Ponceau $\mathrm{S}, 5 \%$ acetic acid) to show transfer efficiency of proteins. After blocked with 5\% non-fat milk in TBST (20 $\mathrm{mM}$ Tris-HCL, $137 \mathrm{mM} \mathrm{NaCl}$ and $0.1 \%$ Tween-20, $\mathrm{pH} 8.0)$ for $1 \mathrm{~h}$, membranes were incubated with monoclonal anti $\alpha$ - $(1: 2,000), \beta$ - $(1: 1,000)$ or $\gamma$ - $(1: 10,000)$ tubulin antibody (SigmaAldrich, St Louis, MO) for $1 \mathrm{~h}$ at room temperature. Membranes were washed with TBST by three times, and subsequently incubated with anti-mouse IgG secondary antibody conjugated horseradish peroxidase (1:5,000, Pierce, Rockford, IL) for $1 \mathrm{~h}$ at room temperature. The chemiluminescence signals were detected using SuperSignal ${ }^{\circledR}$ West Dura Extended Duration reagents (Pierce, Rockford, IL) and digital images were captured by FluoChem ${ }^{\mathrm{TM}} 8800$ system (Alpha Innotech, San Leandro, CA). The same membrane was reblotted with an anti-actin or anti-Erk1/2 to normalize the quantity of the protein on the blot. The data were evaluated by densitmetric analysis using Image $\mathrm{J} 1.37 \mathrm{f}$ software $(\mathrm{NIH})$.

\subsection{Morphology analysis}

Cells were seeded in 24-well plates at a density of $2 \times 10^{4} /$ well and grown under the conditions described above for $48 \mathrm{~h}$. Cells were then treated with PEITC $(20 \mu \mathrm{M})$ or PITC $(30 \mu \mathrm{M})$ in the presence or absence of $5 \mathrm{mM} \mathrm{NAC}$ for $2 \mathrm{~h}$. Photomicrographs were obtained using $100 \times$ magnification by a microscopy (Olympus IX70, Tokyo, Japan) equipped with a digital camera (DP-12, Tokyo, Japan).

\section{Results}

\subsection{PEITC induced cell cycle arrest}

We analyzed cell cycle distribution by flow cytometry in DU145 and PC-3 PCa cells treated by PEITC or PITC. As shown in Table 1, both of the cell lines showed a significant increase in the $\mathrm{G}_{2}-\mathrm{M}$ phase by PEITC ( 10 and $20 \mu \mathrm{M}$ in PC-3 and $20 \mu \mathrm{M}$ in DU145) treatment compared with no treatment. PEITC treatment also caused a significant reduction in the $\mathrm{G}_{0}-\mathrm{G}_{1}$-phase in both of cell lines compared with no treatment. Interestingly, PEITC treatment caused an increase of S phase cells in DU145 but a decrease of them in PC-3. On the other hand, PITC, having a close structure to PEITC except for the lack of a $-\mathrm{CH}_{2}$ spacer that links the aromatic ring to the $-\mathrm{N}=\mathrm{C}=\mathrm{S}$ moiety, did not affect cell cycle in both cell lines.

\subsection{PEITC reduced $\alpha$ - and $\beta$ - tubulin expressions in prostate cancer cell lines}

Since it has been demonstrated that tubulins are associated with cell cycle, we then carried out western blot to determine the expression levels of tubulin isoforms in prostate cancer cells with PEITC treatment. As shown in Figure 1, PEITC inhibited the expression of $\alpha$ - and $\beta$ - tubulins, while PITC had no effect on their expression in PC-3 cells. The inhibition was observed at all investigated time $(2,8$, and $24 \mathrm{hr})$, which indicate the suppression effect of PEITC can last for at least 24 hours. However, $\gamma$-tubulin was not affected by PEITC treatment at any time (data not shown here).

The effect of PEITC on tubulin expression was further examined in other PCa cell lines including DU145, C4-2B, and LNCaP (Figure 2). The results showed that PEITC strongly inhibited both of tubulin expressions in DU145 and LNCaP cells, $20 \mu \mathrm{M}$ of PEITC can inhibit their expression in C4-2B cells. However, PITC had no effect on tubulin expression in all cell 
lines treated. Similar to cell arrest experiment (Table 1), these results also indicate that the structural difference between PEITC and PITC could have different biological function.

To determine if the effect of PEITC on tubulins was cancer cell specific, we used a normal prostate epithelial cell line RWPE1, which was established from a histologically normal adult human prostate by immortalized with the human papillomavirus 18. Interestingly, PEITC treatment neither inhibited $\alpha$-tubulin expression nor $\beta$-tubulin expression in RWPE1 cells as showed in Fig. 2G.

\subsection{Antioxidant abrogated reduction of $\alpha$ - and $\beta$ - tubulin expression by PEITC}

Several studies suggested that cellular effects of PEITC and other ITCs may be mediated, at least in part, by their ability to produce reactive oxygen species (ROS). (Vanaja et al., 2002; Singh et al., 2005; Trachootham et al., 2006) To examine whether PEITC-induced reduction in tubulin expression was mediated by ROS, we carried out western blot to analyze the effect of PEITC on the tubulin expression with DU145, PC-3, and LNCaP cells in the presence or absence of an antioxidant NAC. As shown in Figure 3, the PEITC-induced reduction of both $\alpha$ - and $\beta$ - tubulins was dramatically attenuated by treatment with NAC.

In addition, PEITC (Figure 4, panel B, G, L) induced cell morphological change, including cell rounding and subsequently floating, while PITC (panel C, H, M) and NAC (panel D, I, N) had no effect on PC-3, DU145, and LNCaP cells. NAC treatment could block morphological change induced by PEITC (panel E, J, O).

\subsection{Proteasome inhibitor abrogated reduction of $\alpha$ - and $\beta$ - tubulin expression by PEITC}

To investigate whether PEITC-induced tubulin reduction was mediated by proteasome pathway, western blot was used to analyze the effect of PEITC on tubulin expression in the presence or absence of a proteasome inhibitor MG132. As shown in Figure 5, suppressive effect of PEITC on tubulins was abrogated by presence of MG132. This result indicates that PEITC-induced tubulin degradation may be directly or indirectly mediated by proteasome pathway.

\section{Discussion}

Microtubules are the major cytoskeletal components whose functions include intracellular transport, cell signaling, and cell division that are crucial for the survival of eukaryotes. (Desai et al., 1997) The dynamic property of $\alpha$ - and $\beta$ - tubulins that make up heterodimer subunits of microtubules are especially important for processes of mitosis and cell division, and it has been received much attention as a favorite target of treating or preventing malignancies. Many of agents that can target tubulins have been discovered in natural products such as Taxus and Catharanthus. (Nagle et al., 2006) Recent studies showed that exposure to ITCs, including allyl ITC (AITC) and sulforaphane resulted in cell cycle arrest associated with altered tubulin polymerization, suggesting that the effects of ITCs may be related to tubulin functions. Other ITCs such as PEITC could also induce $\mathrm{G}_{2}-\mathrm{M}$ phase cell cycle arrest in several cancer cell lines including prostate cancer cells. (Chiao et al., 2000; Visan et al., 2004) Those tubulin-binding drugs as mentioned above can act as inhibitors in G2/M phase transition, providing evidence that the dysregulation of tubulin dynamics may disrupt G2/M transition and, subsequently, induce the cell-cycle arrest in tumor cells. (Wang et al., 1999) It also has been reported that PEITC-induced G2/M arrest was associated with proteasome-mediated degradation of Cdk1 and Cdc25C. (Xiao et al., 2004) However, veryXiao little is known regarding mechanisms of effects of PEITC on microtubules in the cells. In the present study, we found that the treatment of PEITC results in reduction of both $\alpha$ - and $\beta$ - tubulin expression. In consistent with other studies, (Xiao et al., 2005; Lui et al., 2003) PITC, a structural analogue of PEITC by missing 
a $-\mathrm{CH}_{2}$ spacer, had no effect on tubulin expressions and cell proliferation/cell cycle alteration in investigated PCa cell lines. In addition to G2-M arrest, we found that PEITC treatment caused an increase of S phase cells in DU145. Whether different cell lines may have different responses is not clear at present time. However, as compared the tubulin protein levels inhibited by PEITC in PC-3 cells (Fig.1) with that in DU145 cells (Fig.2), We speculate that PEITC might have stronger inhibitory effects on PC-3 than DU145. We suspect this might be related to the weaker effects on cell cycle by PEITC in DU145 than in PC-3.

It has been suggested that PEITC treatment can induce ROS generation and result in apoptosis. (Trachootham et al., 2006) In this study, we found that the cell rounding and the reduction of $\alpha$ - and $\beta$ - tubulin expression by PEITC treatment were abrogated by the presence of an ROS inhibitor, NAC. At the same time, we found that a decrease in protein levels of $\alpha$ - and $\beta$ - tubulins induced by PEITC was significantly blocked by a proteasome inhibitor MG132, however, MG132 alone had no effect on tubulin expression. Recent studies showed that increased ROS is involved in cell cycle arrest and cell death caused by tubulin-targeted agents. (Alexandre et al., 2006; Ramanathan et al., 2005) And the ubiquitin-proteasome pathway is the major nonlysosomal system for degradation of intracellular proteins. Inhibition of proteasome causes cell cycle arrest and apoptosis. (Almond et al., 2002; Coux et al., 1996) Based on our studies, we hypothesized ROS generation and ubiquitin-proteasome might relate to the inhibition of PEITC on tubulins expression.

Like those reported above, our interpretation of the effect of NAC on oxidative stress by PEITC was based on the suggestion of some early studies. (Chen et al., 1998) Indeed, those thiol containing antioxidants such as glutathione or 2-mercaptoethanol might have similar effect to NAC. Alternative explanation was proposed by other studies led by Xu. (Xu et al., 2001) They suggested that thiocarbamoylation of glutathione or the cysteinyl thiol group containing proteins by PEITC may be a major mechanism for activation of certain critical cellular events by PEITC.

A pharmacokinetic study showed that an oral dose of $40 \mathrm{mg}$ PEITC resulted in a plasma concentration of 1-2 $\mu \mathrm{M}$, (Liebes et al., 2001) and it has been shown that i.p. injection of 5 $\mu \mathrm{M}$ PEITC (3 times per week) retarded the growth of prostate cancer xenografts when given 1 day before tumor implantation. Although this dosage of PEITC had little effect on wellestablished tumor, combination of PEITC with curcumin was more effective, (Khor et al., 2006) suggesting that combination of PEITC with other agents may enhance its anticancer activity. The present study showed that PEITC can inhibit the tubulin expressions in several prostate cancer cell lines, which may contribute to its anticancer action. Moreover, PEITC has been well confirmed to have little side effect on the normal cells. (Trachootham et al., 2006) Collectively, it is suggested that high concentration of PEITC or low concentration of PEITC combined with other chemicals might be feasible. However, more vigorous experiments including in vivo studies will have to be included in the near future studies to further investigate the regulatory mechansims involved in the PEITC inhibition on tubulin expressions and G2$\mathrm{M}$ arrest.

\section{Abbreviations}

PEITC, Phenethyl isothiocyanate; ITC, isothiocyanates; NAC, N-acetyl-L-cysteine.

\section{Acknowledgements}

The work in this manuscript is in part supported by NIH grants CA88900 and 91956. 


\section{References}

Alexandre J, Batteux F, Nicco C, Chereau C, Laurent A, Guillevin L, Weill B, Goldwasser F. Accumulation of hydrogen peroxide is an early and crucial step for paclitaxel-induced cancer cell death both in vitro and in vivo. Int J Cancer 2006;119(1):41-48. [PubMed: 16450384]

Almond JB, Cohen GM. The proteasome: a novel target for cancer chemotherapy. Leukemia 2002;16 (4):433-443. [PubMed: 11960320]

Butler R, Mitchell SH, Tindall DJ, Young CY. Nonapoptotic cell death associated with S-phase arrest of prostate cancer cells via the peroxisome proliferator-activated receptor gamma ligand, 15-deoxydelta12,14-prostaglandin J2. Cell Growth Differ 2000;11(1):49-61. [PubMed: 10672903]

Chen YR, Wang W, Kong T, Tan TH. Molecular mechanism of c-Jun Nterminal kinase-mediated apoptosis induced by anticarcinogenic isothiocyanates. J Biol Chem 1998;273:1769-1775. [PubMed: 9430725]

Chiao JW, Chung F, Krzeminski J, Amin S, Arshad R, Ahmed T, Conaway CC. Modulation of growth of human prostate cancer cells by the Nacetylcysteine conjugate of phenethyl isothiocyanate. Int J Oncol 2000;16(6):1215-1219. [PubMed: 10811998]

Coux O, Tanaka K, Goldberg AL. Structure and functions of the 20S and 26S proteasomes. Annu Rev Biochem 1996;65:801-847. [PubMed: 8811196]

Desai A, Mitchison TJ. Microtubule polymerization dynamics. Annu Rev Cell Dev Biol 1997;13:83117. [PubMed: 9442869]

Hadfield JA, Ducki S, Hirst N, McGown AT. Tubulin and microtubules as targets for anticancer drugs. Prog Cell Cycle Res 2003;5:309-325. [PubMed: 14593726]

Higdon JV, Delage B, Williams DE, Dashwood RH. Cruciferous vegetables and human cancer risk: epidemiologic evidence and mechanistic basis. Pharmacol Res 2007;55(3):224-236. [PubMed: 17317210]

Howard J, Hyman AA. Dynamics and mechanics of the microtubule plus end. Nature 2003;422(6933): 753-758. [PubMed: 12700769]

Jemal A, Siegel R, Ward E, Murray T, Xu J, Thun MJ. Cancer statistics 2007. CA Cancer J Clin 2007;57 (1):43-66. [PubMed: 17237035]

Khor TO, Keum YS, Lin W, Kim JH, Hu R, Shen G, Xu C, Gopalakrishnan A, Reddy B, Zheng X, Conney AH, Kong AN. Combined inhibitory effects of curcumin and phenethyl isothiocyanate on the growth of human PC-3 prostate xenografts in immunodeficient mice. Cancer Res 2006;66(2): 613-621. [PubMed: 16423986]

Liebes L, Conaway CC, Hochster H, Mendoza S, Hecht SS, Crowell J, Chung FL. High-performance liquid chromatography-based determination of total isothiocyanate levels in human plasma: Application to studies with 2-phenethyl isothiocyanate. Anal. Biochem 2001;291:279-289. [PubMed: 11401302]

Lui VW, Wentzel AL, Xiao D, Lew KL, Singh SV, Grandis JR. Requirement of a carbon spacer in benzyl isothiocyanate-mediated cytotoxicity and MAPK activation in head and neck squamous cell carcinoma. Carcinogenesis 2003;24(10):1705-1712. [PubMed: 12896907]

Manfredi JJ, Parness J, Horwitz SB. Taxol binds to cellular microtubules. J Cell Biol 1982;94:688-696. [PubMed: 6127342]

Nagle A, Hur W, Gray NS. Antimitotic agents of natural origin. Curr Drug Targets 2006;7(3):305-326. [PubMed: 16515529]

Ramanathan B, Jan KY, Chen CH, Hour TC, Yu HJ, Pu YS. Resistance to paclitaxel is proportional to cellular total antioxidant capacity. Cancer Res 2005;65(18):8455-8460. [PubMed: 16166325]

Rowinsky EK. The development and clinical utility of the taxane class of antimicrotubule chemotherapy agents. Annu Rev Med 1997;48:353-374. [PubMed: 9046968]

Singh SV, Srivastava SK, Choi S, Lew KL, Antosiewicz J, Xiao D, Zeng Y, Watkins SC, Johnson CS, Trump DL, Lee YJ, Xiao H, Herman-Antosiewicz A. Sulforaphane-induced cell death in human prostate cancer cells is initiated by reactive oxygen species. J Biol Chem 2005;280(20):19911-19924. [PubMed: 15764812]

Trachootham D, Zhou Y, Zhang H, Demizu Y, Chen Z, Pelicano H, Chiao PJ, Achanta G, Arlinghaus RB, Liu J, Huang P. Selective killing of oncogenically transformed cells through a ROS-mediated 
mechanism by beta-phenylethyl isothiocyanate. Cancer Cell 2006;10(3):241-252. [PubMed: 16959615]

Vanaja DK, Mitchell SH, Toft DO, Young CY. Effect of geldanamycin on androgen receptor function and stability. Cell Stress Chaperones 2002;7(1):55-64. [PubMed: 11894840]

Visanji JM, Duthie SJ, Pirie L, Thompson DG, Padfield PJ. Dietary isothiocyanates inhibit Caco-2 cell proliferation and induce G2/M phase cell cycle arrest, DNA damage, and G2/M checkpoint activation. J Nutr 2004;134(11):3121-3126. [PubMed: 15514285]

Walczak JR, Carducci MA. Prostate cancer: a practical approach to current management of recurrent disease. Mayo Clin Proc 2007;82(2):243-249. [PubMed: 17290734]

Wang LG, Liu XM, Kreis W, Budman DR. The effect of antimicrotubule agents on signal transduction pathways of apoptosis: a review. Cancer Chemother Pharmacol 1999;44:355-361. [PubMed: 10501907]

Wilson L, Jordan MA. Microtubule dynamics: taking aim at a moving target. Chem Biol 1995;2:569573. [PubMed: 9383460]

Xiao D, Lew KL, Zeng Y, Xiao H, Marynowski SW, Dhir R, Singh SV. Phenethyl isothiocyanate-induced apoptosis in PC-3 human prostate cancer cells is mediated by reactive oxygen species-dependent disruption of the mitochondrial membrane potential. Carcinogenesis 2006;27(11):2223-2234. [PubMed: 16774948]

Xiao D, Choi S, Lee YJ, Singh SV. Role of mitogen-activated protein kinases in phenethyl isothiocyanateinduced apoptosis in human prostate cancer cells. Mol Carcinog 2005;43(3):130-140. [PubMed: 15880419]

Xiao D, Johnson CS, Trump DL, Singh SV. Proteasome-mediated degradation of cell division cycle 25C and cyclin-dependent kinase 1 in phenethyl isothiocyanate-induced G2-M-phase cell cycle arrest in PC-3 human prostate cancer cells. Mol Cancer Ther 2004;3(5):567-575. [PubMed: 15141014]

Xiao D, Zeng Y, Choi S, Lew KL, Nelson JB, Singh SV. Caspase-dependent apoptosis induction by phenethyl isothiocyanate, a cruciferous vegetablederived cancer chemopreventive agent, is mediated by Bak and Bax. Clin Cancer Res 2005;11(7):2670-2679. [PubMed: 15814648]

Ramanathan B, Jan KY, Chen CH, Hour TC, Yu HJ, Pu YS. Resistance to paclitaxel is proportional to cellular total antioxidant capacity. Cancer Res 2005;65(18):8455-8460. [PubMed: 16166325]

$\mathrm{Xu} \mathrm{K}$, Thornalley PJ. Involvement of glutathione metabolism in the cytotoxicity of the phenethyl isothiocyanate and its cysteine conjugate to human leukaemia cells in vitro. Biochem Pharmacol 2001;61(2):165-177. [PubMed: 11163331] 
A

$\operatorname{PITC}(\mu \mathrm{M}) \quad-\quad 30 \quad-\quad-$

$\begin{array}{llllll}\operatorname{PEITC}(\mu \mathrm{M}) \quad- & - & 5 & 10 & 20\end{array}$

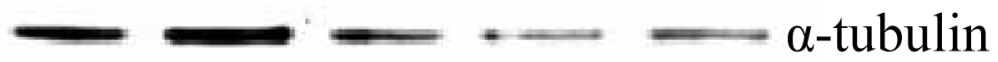

B
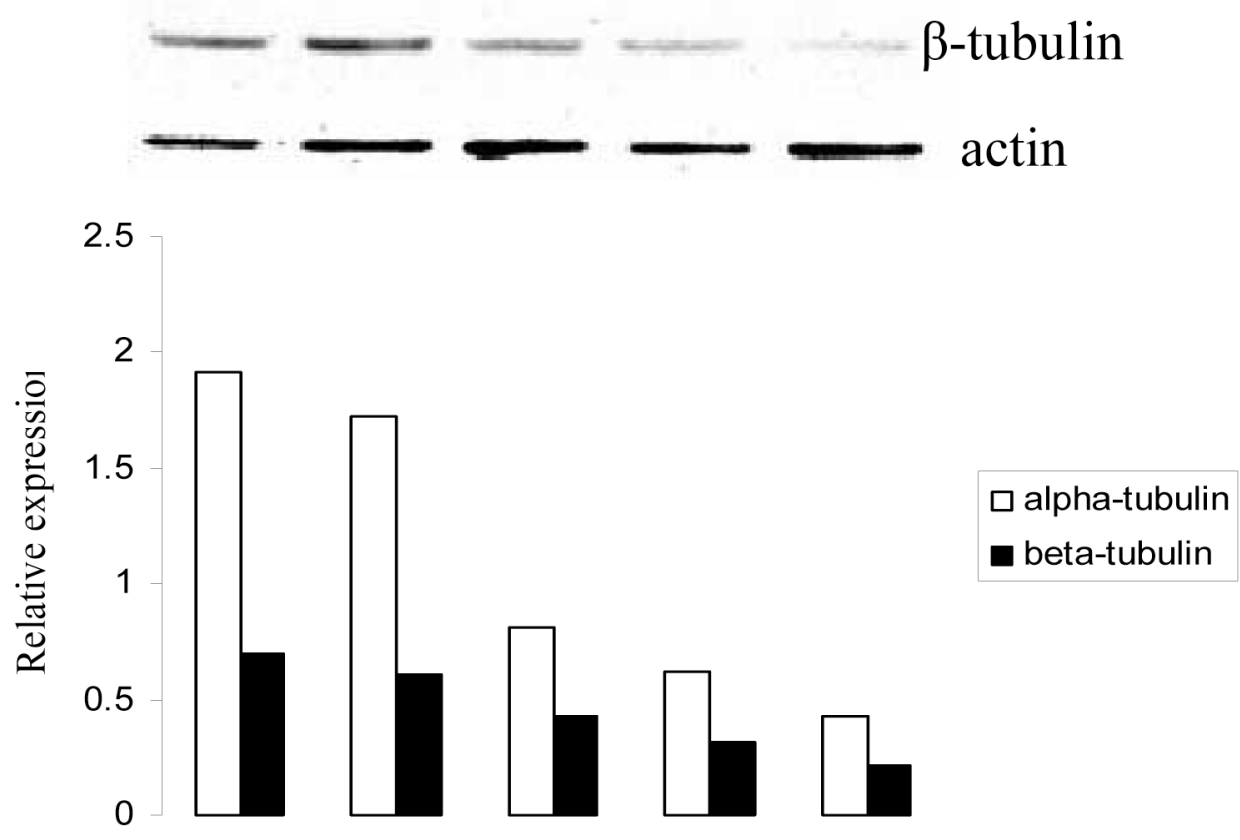
$\mathrm{C}$

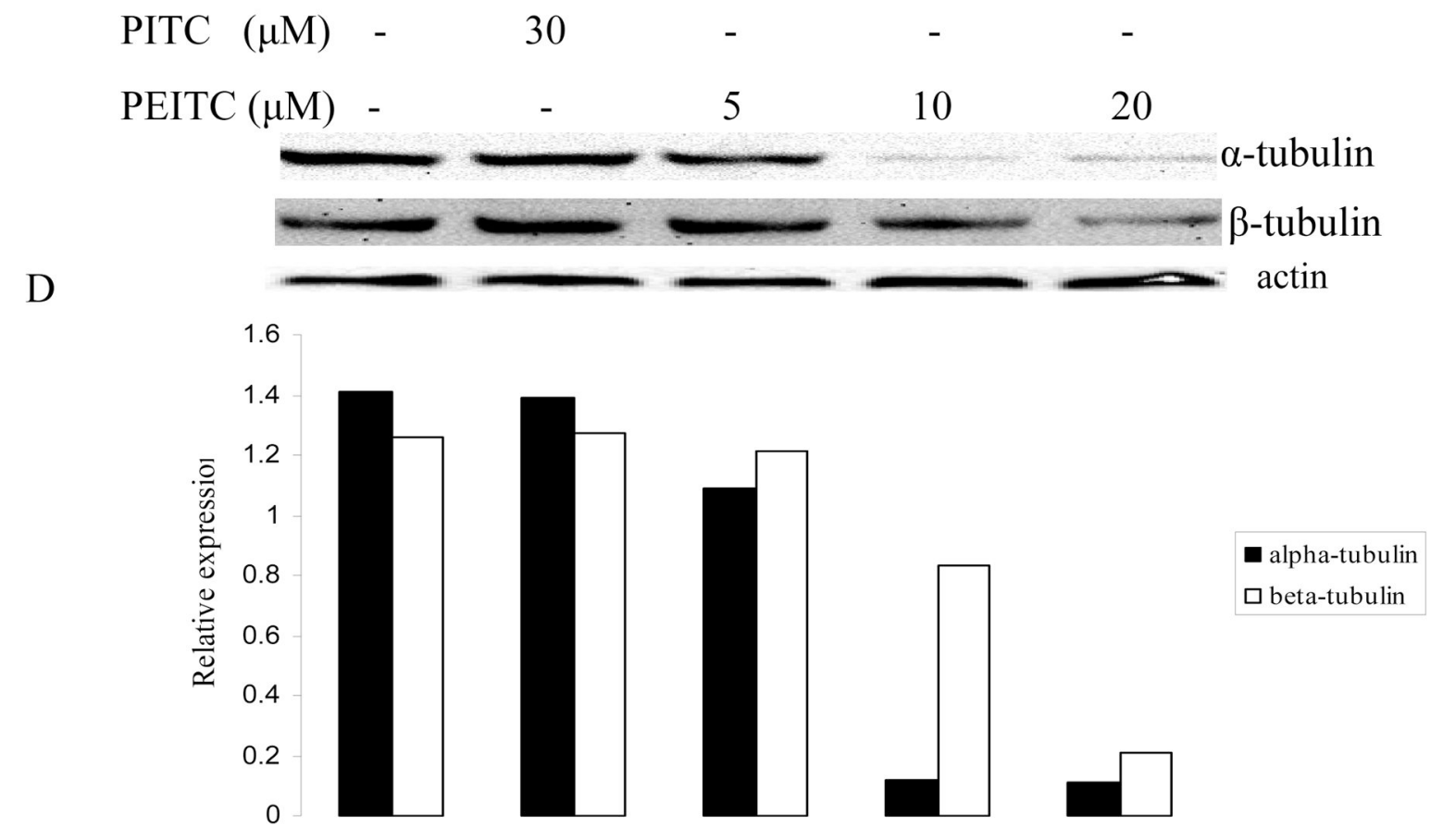


E
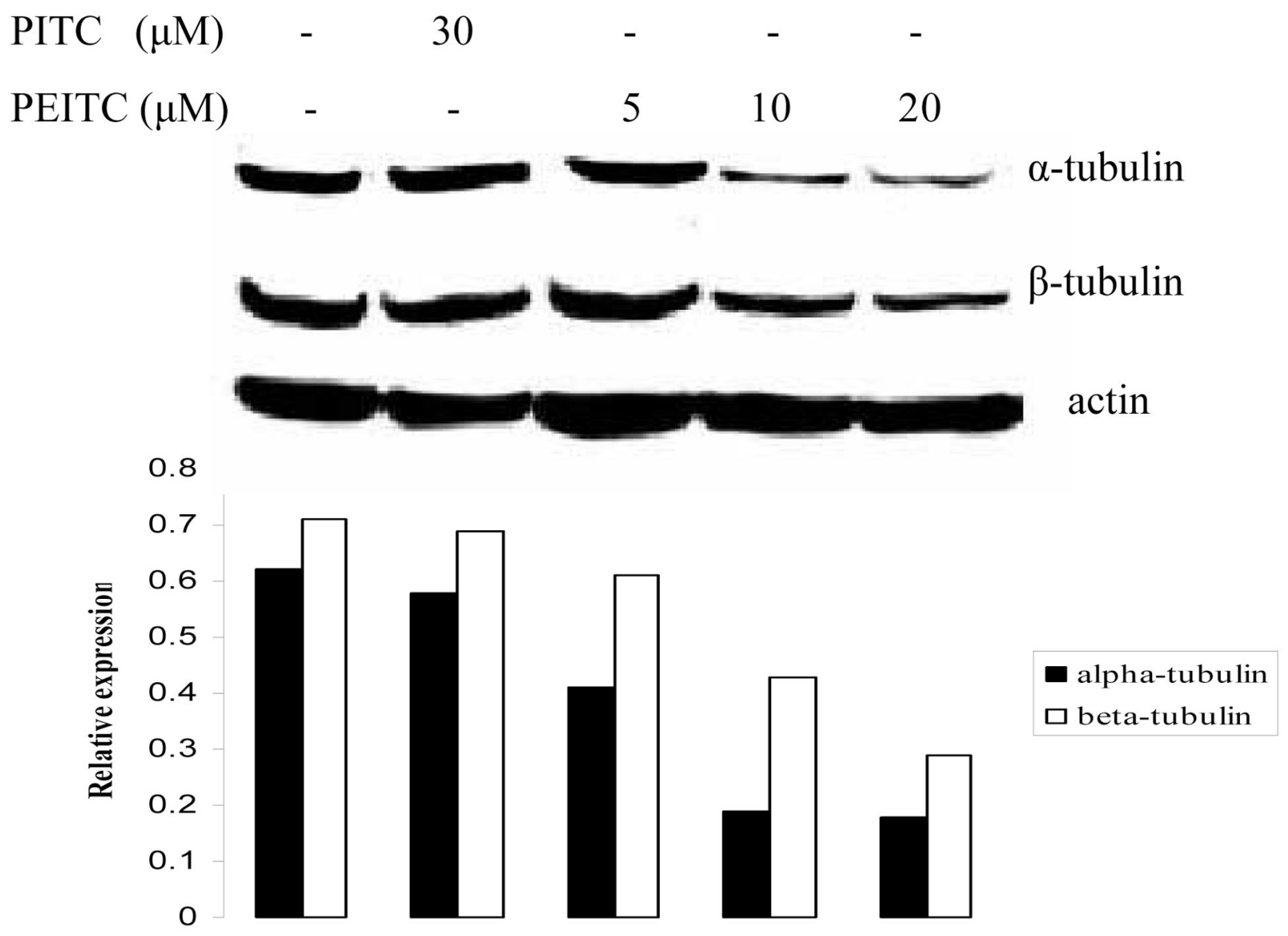

Figure 1.

Effects of PITC and PEITC on tubulin expression in PC-3 cells. Cells were treated by PITC $(30 \mu \mathrm{M})$, or PEITC $(0,5,10$, or $20 \mu \mathrm{M})$ for $2 \mathrm{~h}(\mathrm{~A}), 8 \mathrm{~h}(\mathrm{C})$, or $24 \mathrm{~h}(\mathrm{E})$. Actin was used as an internal control for protein loading and transfer efficiency, (B), (D), (F) Densitometric measurements of tubulin expression levels were normalized to internal controls and are expressed in relative units 

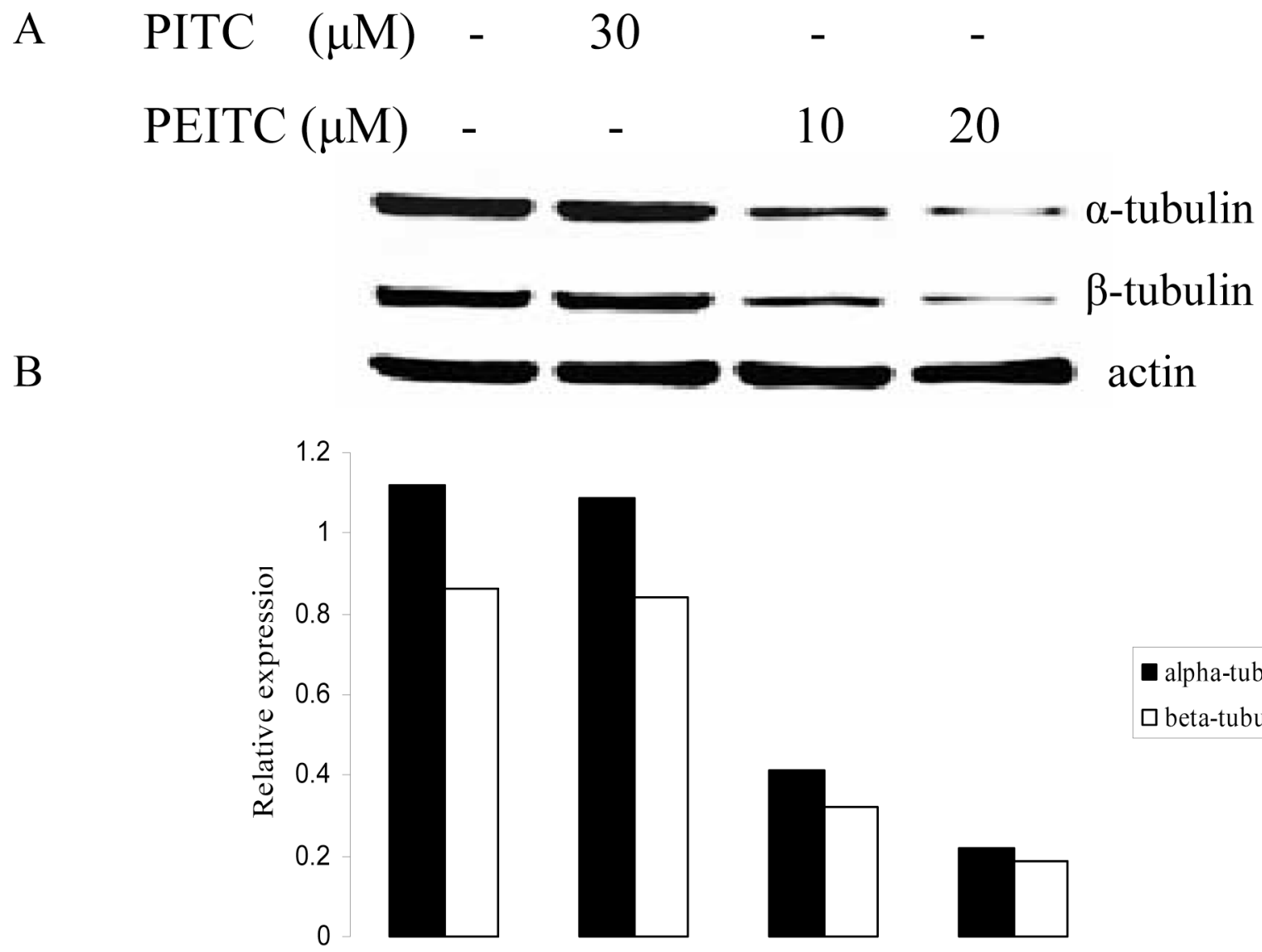

alpha-tubulin

$\square$ beta-tubulin 
C
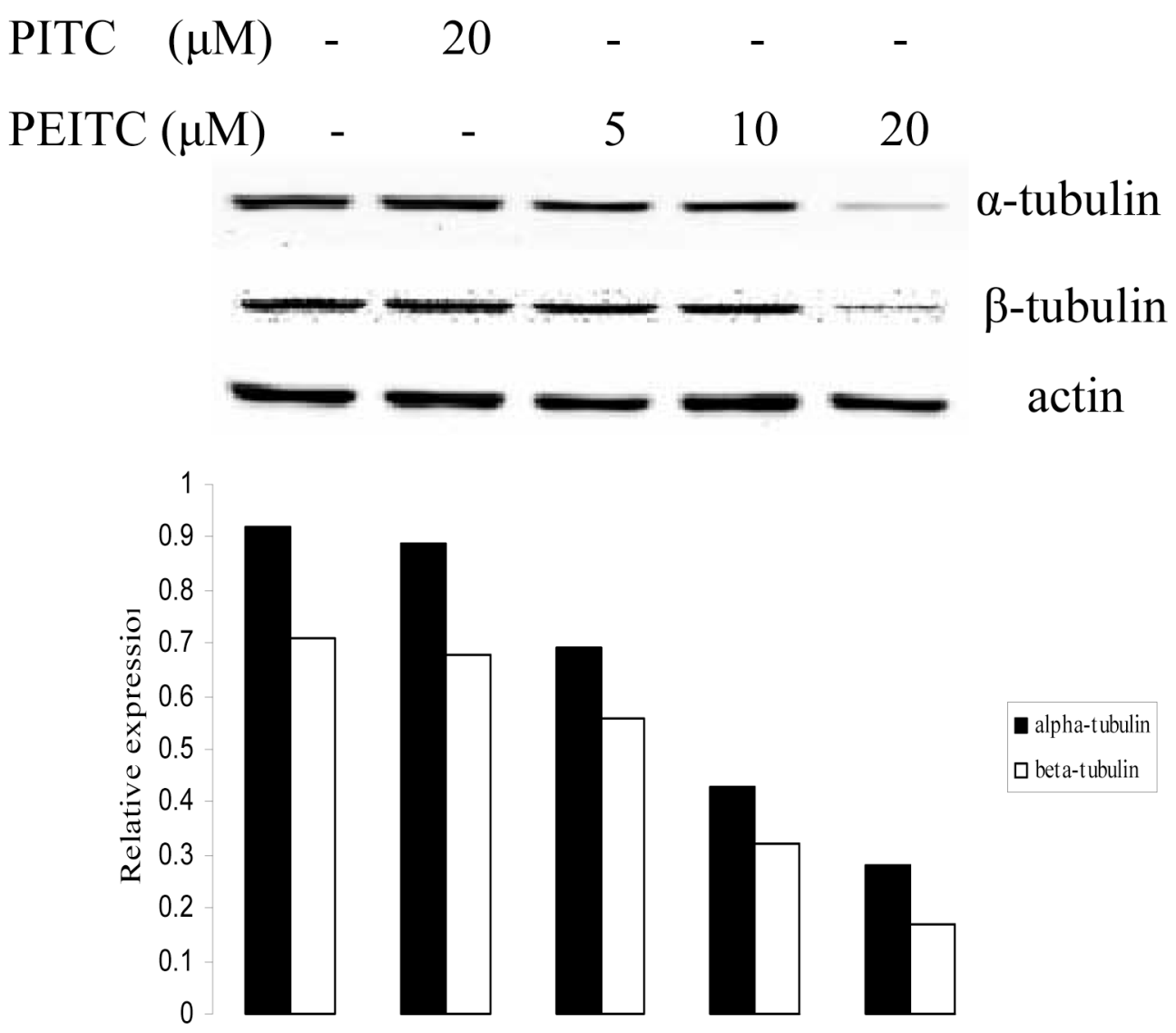
E

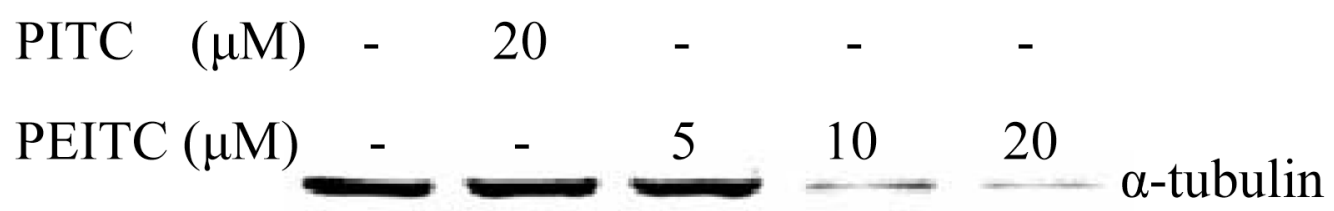

$\mathrm{F}$
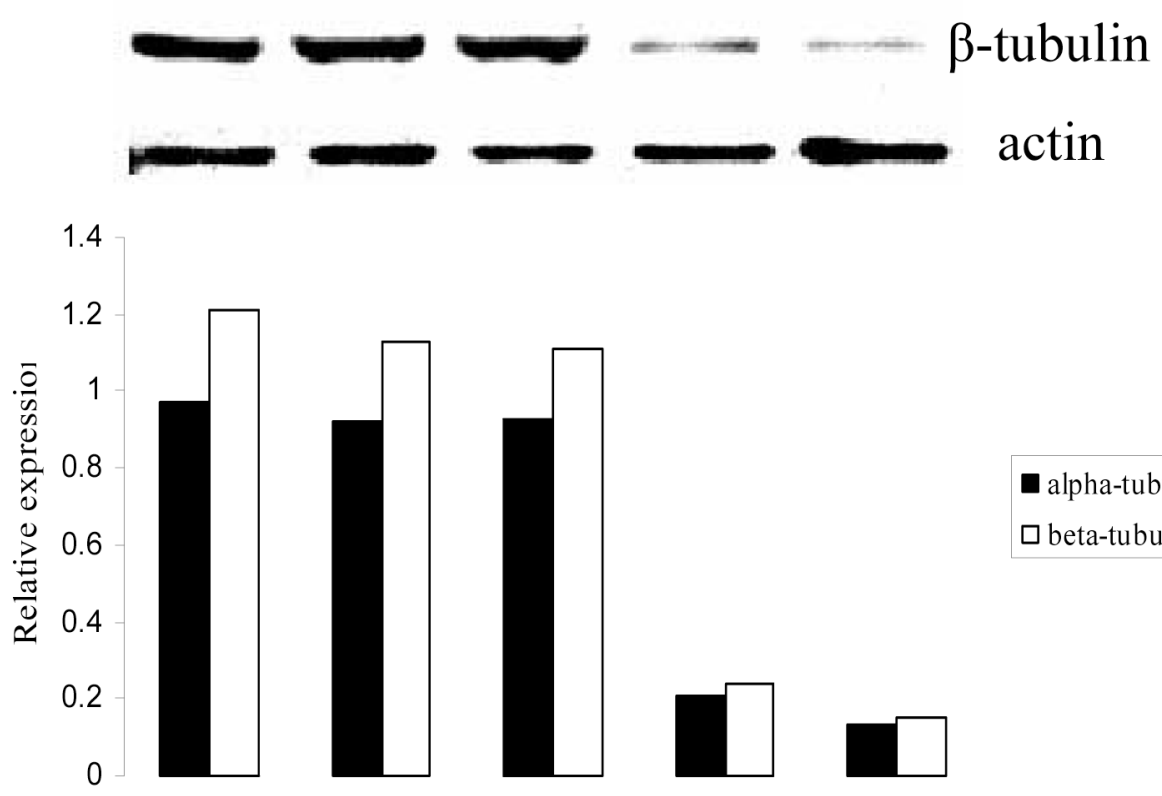

- alpha-tubulin

$\square$ beta-tubulin 
G
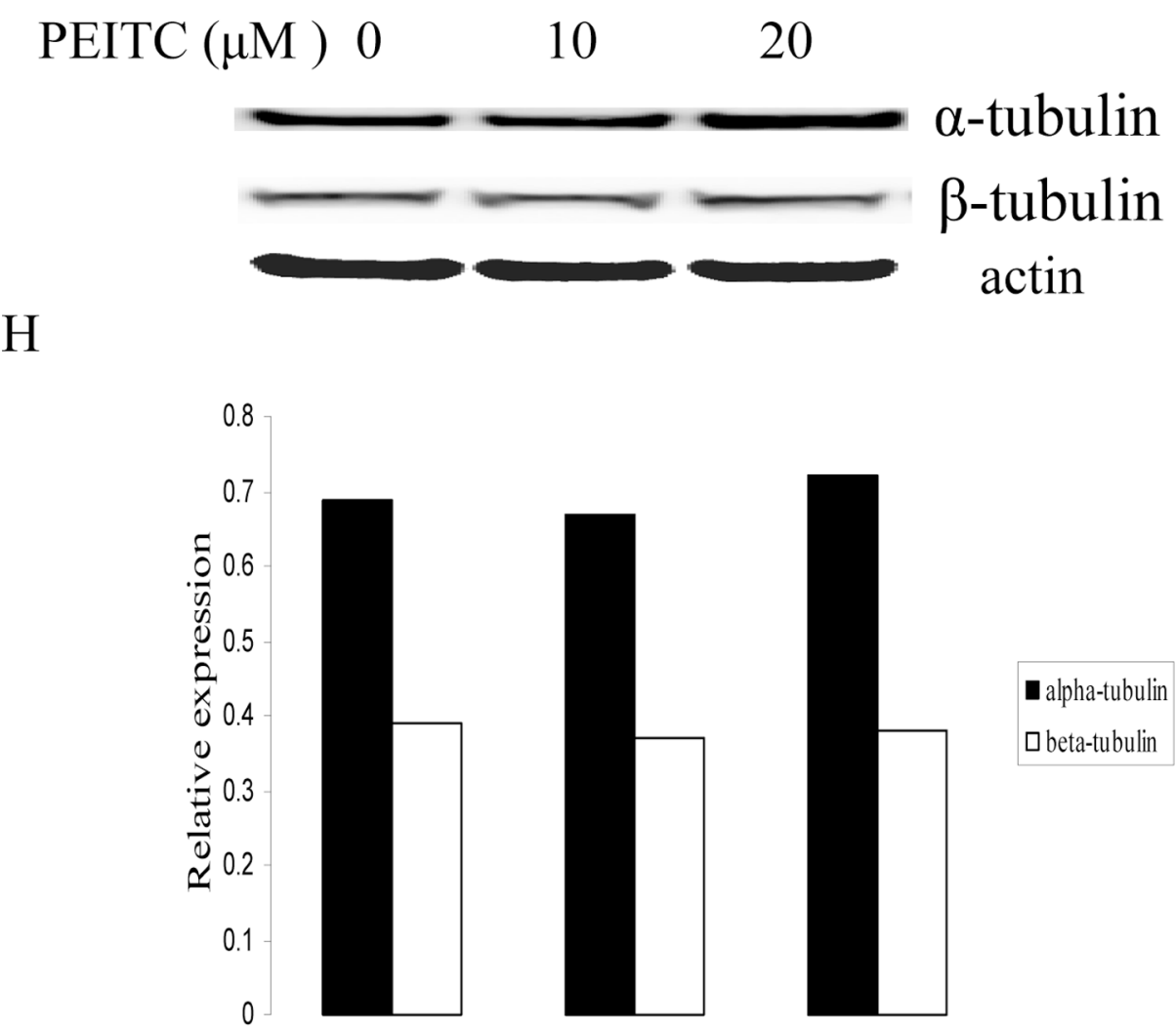

- alpha-tubulin

口beta-tubulin

Figure 2.

Effects of PITC and PEITC on tubulin expression in DU145 (A), C4-2B (C), LNCaP (E) and RWPE1 (G) cells. Cells were treated by PITC $(0,20$ or $30 \mu \mathrm{M})$, or PEITC $(0,5,10$, or $20 \mu \mathrm{M})$ for $24 \mathrm{~h}$. Actin was used as an internal control for protein loading and transfer efficiency, (B), (D), (F) (H) Densitometric measurements of tubulin expression levels were normalized to internal controls and are expressed in relative units 
A

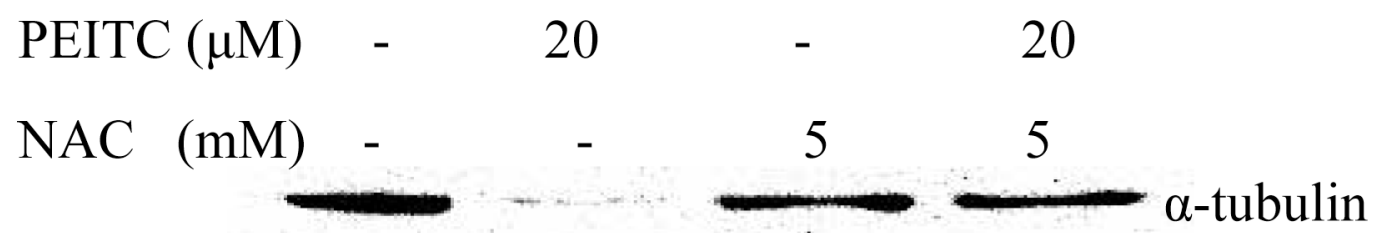

B
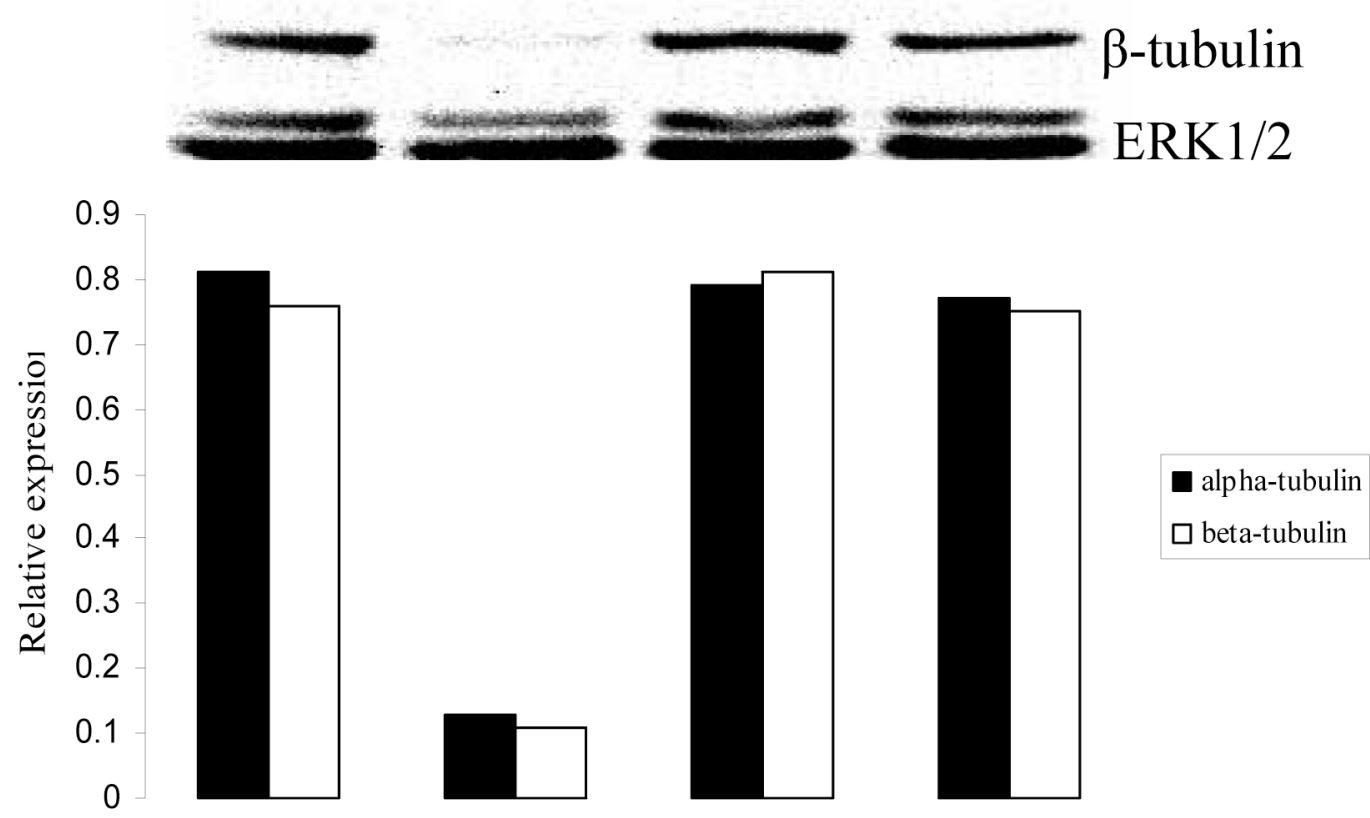
C
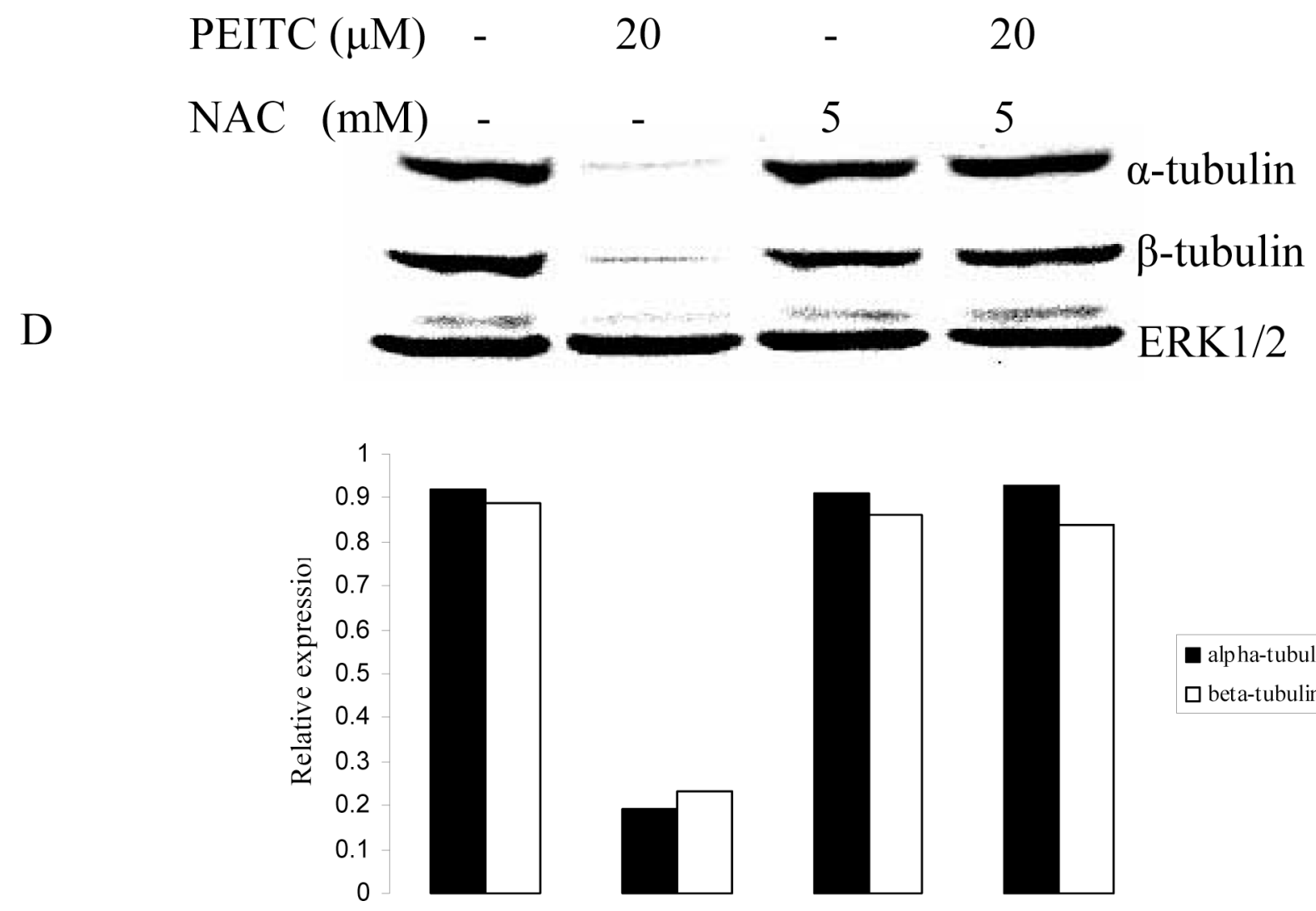

- alpha-tubulin 
$\mathrm{E}$

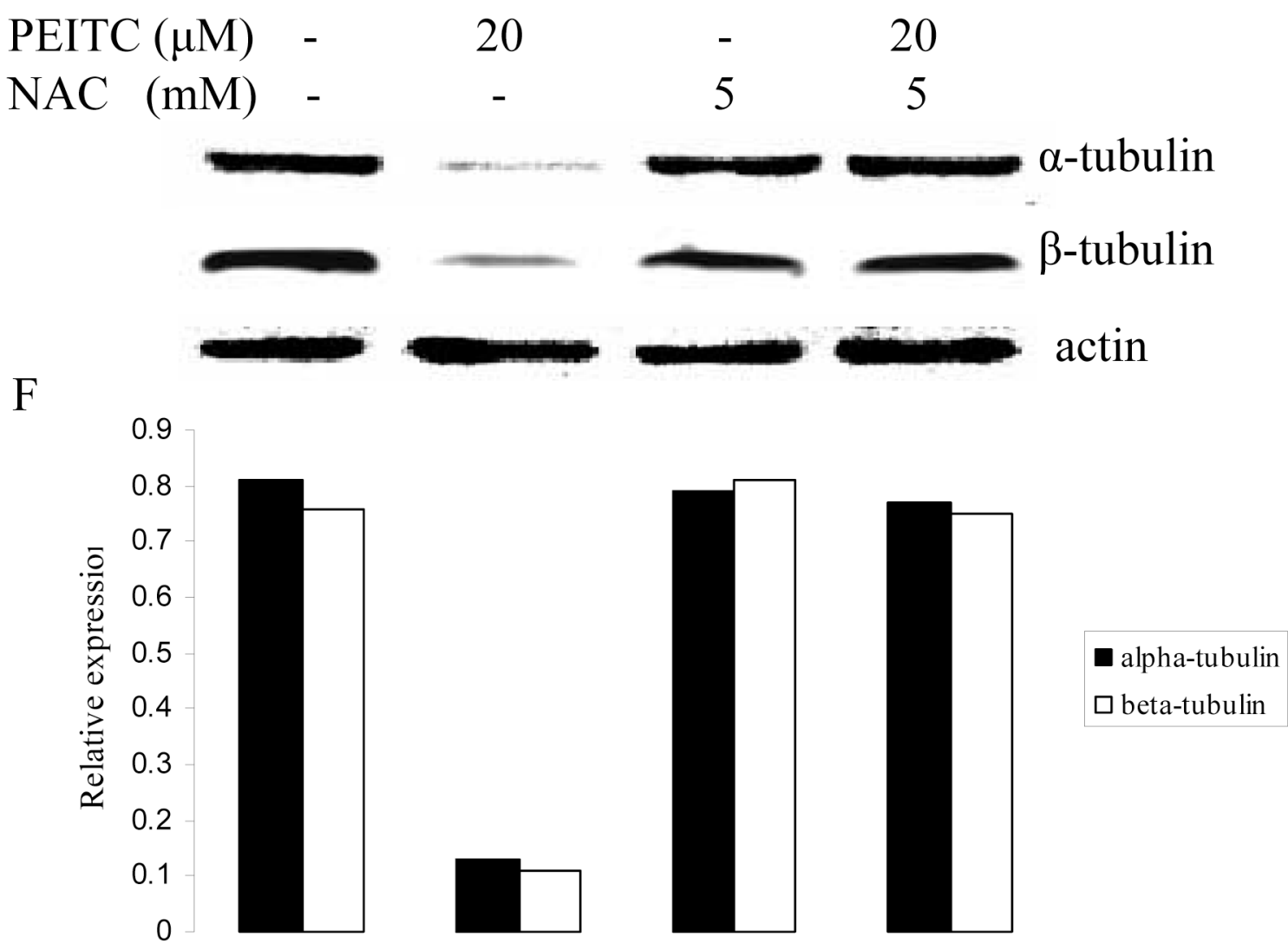

Figure 3.

Effects of NAC on PEITC-induced tubulin reduction in DU145 (A), PC-3 (C), and LNCaP (D) cells. Cells were treated by PEITC $(0$ or $20 \mu \mathrm{M})$, NAC $(0$ or $5 \mathrm{mM})$ or PEITC plus NAC for $24 \mathrm{~h}$. ERK1/2 was used as an internal control for protein loading and transfer efficiency, (B), (D), (F) Densitometric measurements of tubulin expression levels were normalized to internal controls and are expressed in relative units 

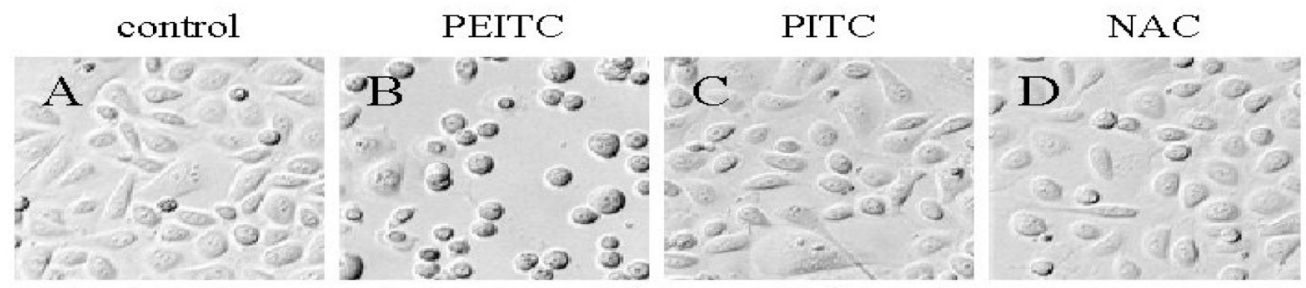

PEITC+NAC
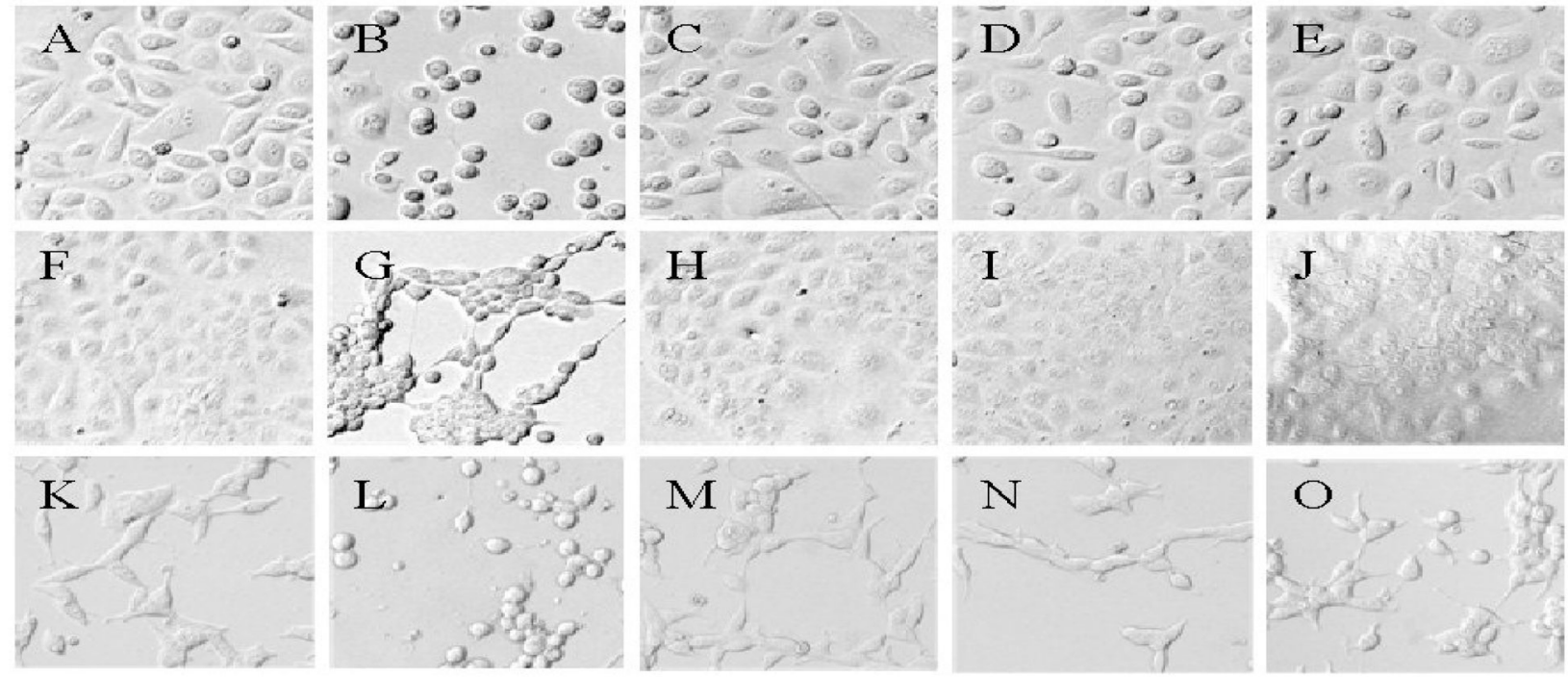

Figure 4.

Morphological changes induced by PEITC $(20 \mu \mathrm{M})$, PITC $(30 \mu \mathrm{M})$ and NAC $(5 \mathrm{mM})$ in PC-3 (A- E), DU145 (F-J), and LNCaP (K-O) cells after $2 \mathrm{~h}$ treatment. 
A

PEITC $(\mu \mathrm{M})-20 \quad-20 \quad-\quad 20$
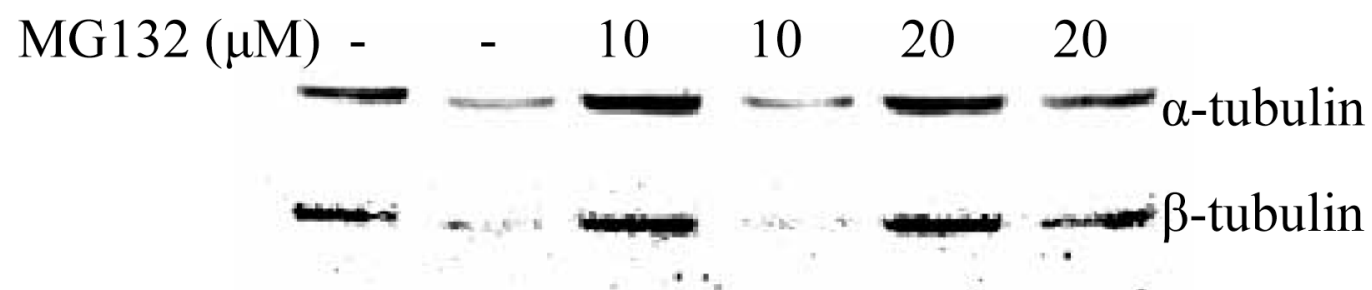

B
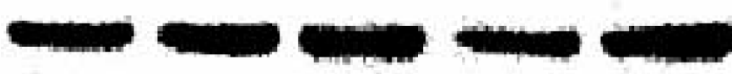

actin

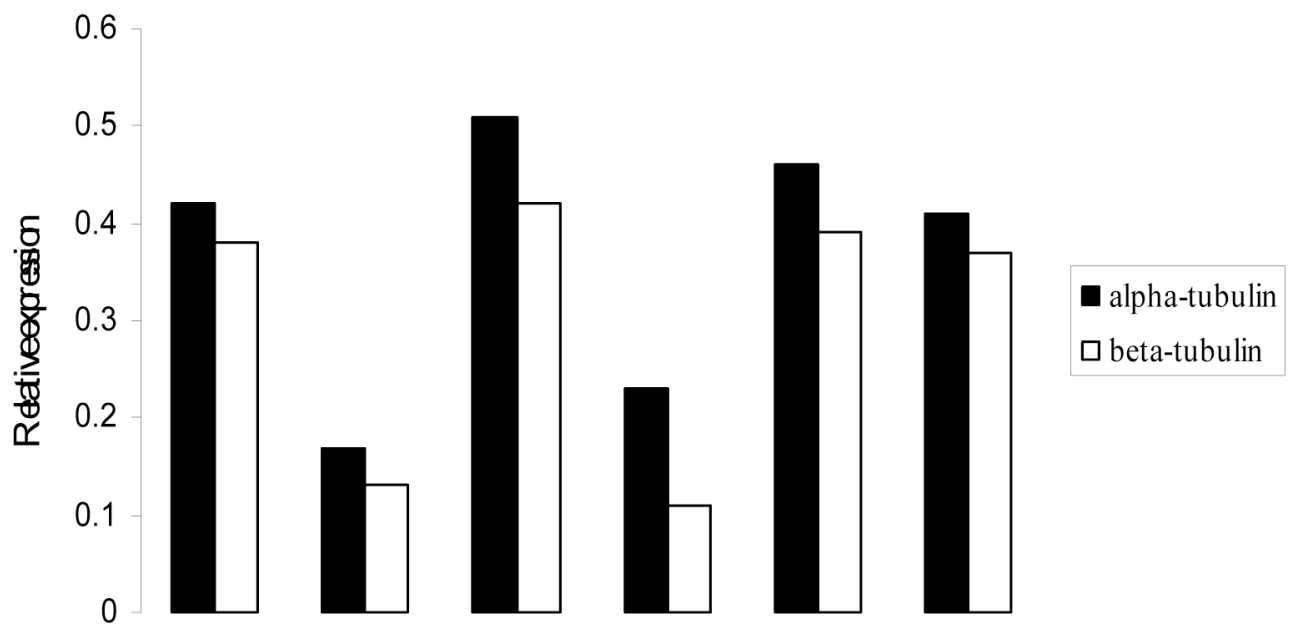


C

PEITC $(\mu \mathrm{M})-20 \quad-\quad 20 \quad-\quad 20$

$\operatorname{MG132}(\mu \mathrm{M})-\quad \begin{array}{lllll}10 & 10 & 20 & 20\end{array}$

$\longrightarrow-\cdots-\alpha$-tubulin

D
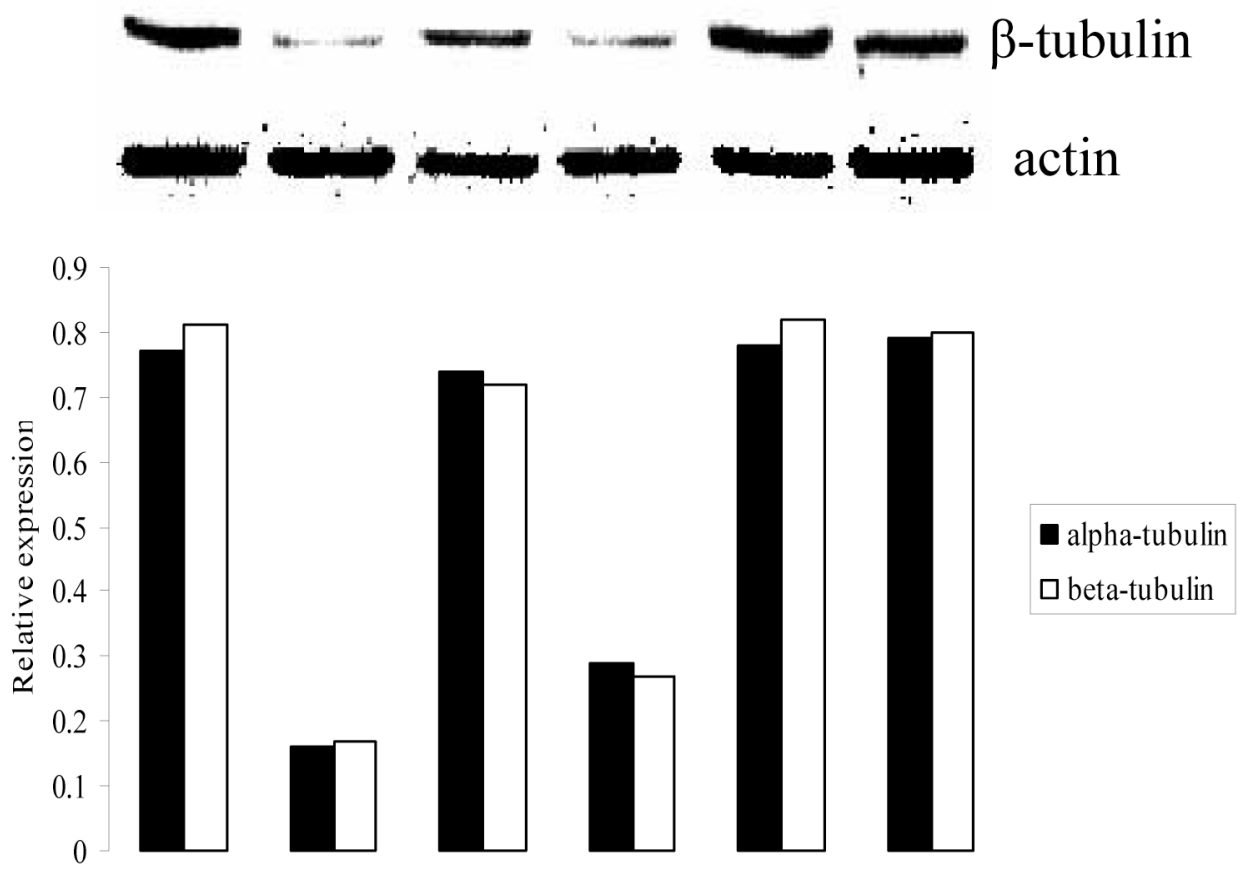

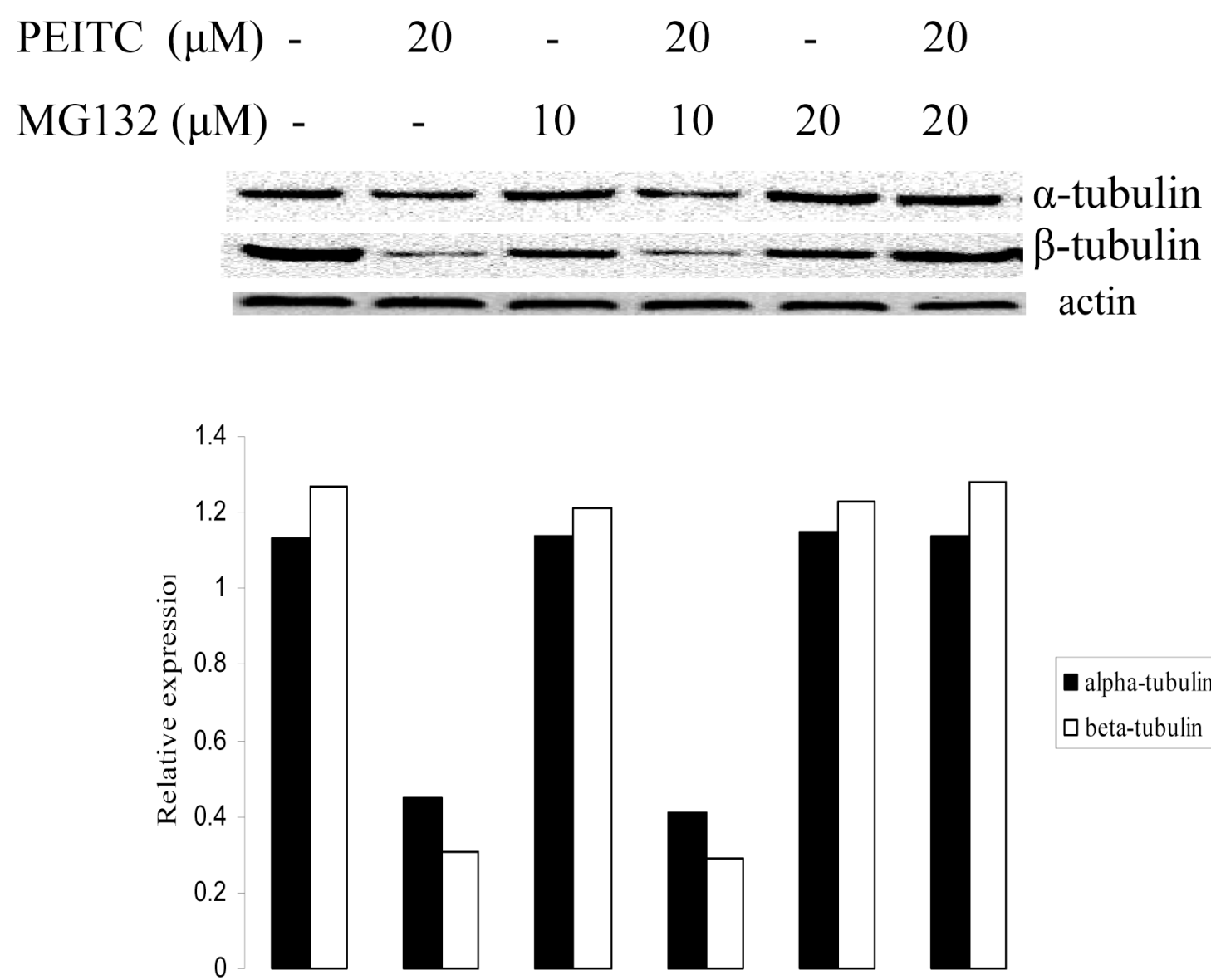

- alpha-tubulin $\square$ beta-tubulin

Figure 5.

Effects of MG-132 on PEITC-induced reduction of tubulin in DU145 (A) and PC-3 (C) cells for $6 \mathrm{~h}$ or in PC-3 cells for $24 \mathrm{~h}(\mathrm{E})$. Actin was used as an internal control for protein loading and transfer efficiency, (B), (D), (F) Densitometric measurements of tubulin expression levels were normalized to internal controls and are expressed in relative units 
Table 1

Effects of PITC and PEITC on DU145 and PC-3 cell cycle

\begin{tabular}{|c|c|c|c|c|}
\hline \multirow[t]{2}{*}{ Cell lines } & \multirow[t]{2}{*}{ Treatment } & \multicolumn{3}{|c|}{$\%$ Cells } \\
\hline & & G0-G1 & $\mathbf{S}$ & G2-M \\
\hline \multirow[t]{4}{*}{ DU145 } & Control & $56.5 \pm 1.2$ & $30.5 \pm 0.5$ & $13.0 \pm 1.6$ \\
\hline & $20 \mu \mathrm{M}$ PITC & $57.1 \pm 2.1$ & $30.0 \pm 0.8$ & $13.3 \pm 1.6$ \\
\hline & $10 \mu \mathrm{M}$ PEITC & $52.6 \pm 1.5$ & $33.2 \pm 1.7$ & $14.1 \pm 0.5$ \\
\hline & $20 \mu \mathrm{M}$ PEITC & $49.1 \pm 1.4^{*}$ & $35.3 \pm 1.4^{*}$ & $21.0 \pm 0.3^{*}$ \\
\hline \multirow[t]{4}{*}{ PC-3 } & Control & $53.6 \pm 1.7$ & $25.7 \pm 1.2$ & $20.7 \pm 1.4$ \\
\hline & $20 \mu \mathrm{M}$ PITC & $55.0 \pm 1.9$ & $24.6 \pm 1.3$ & $20.4 \pm 1.2$ \\
\hline & $10 \mu \mathrm{M}$ PEITC & $47.4 \pm 2.1$ & $20.6 \pm 1.1^{*}$ & $31.9 \pm 1.6^{*}$ \\
\hline & $20 \mu \mathrm{M}$ PEITC & $45.6 \pm 1.7^{*}$ & $22.2 \pm 1.4$ & $31.7 \pm 1.3^{*}$ \\
\hline
\end{tabular}

Cells were treated with PITC or PEITC for $24 \mathrm{~h}$ and then analyzed cell cycle distribution by flow cytometry. Data show means \pm SD for DU145 ( $n=3$ ) and means for PC-3 $(n=2)$.

${ }_{P}^{*}<0.05$, significantly different compared with control. 